\title{
Transatlantica
}

Revue d'études américaines. American Studies Journal

2| 2017

(Hi)stories of American Women: Writings and Rewritings / Call and Answer: Dialoguing the American West in France

\section{Nathan Lyons: In Pursuit of Magic at the George Eastman Museum (Rochester, NY), retrospective or exhibition?}

The exhibition Nathan Lyons: In Pursuit of Magic at the George Eastman Museum, January 25 - June 9, 2019

\section{Bruno Chalifour}

\section{(2) OpenEdition}

\section{Journals}

\section{Electronic version}

URL: https://journals.openedition.org/transatlantica/11136

DOI: 10.4000/transatlantica.11136

ISSN: $1765-2766$

Publisher

Association française d'Etudes Américaines (AFEA)

\section{Electronic reference}

Bruno Chalifour, "Nathan Lyons: In Pursuit of Magic at the George Eastman Museum (Rochester, NY), retrospective or exhibition?", Transatlantica [Online], 2 | 2017, Online since 18 May 2019, connection on 02 February 2023. URL: http://journals.openedition.org/transatlantica/11136 ; DOI: https://doi.org/ 10.4000/transatlantica.11136

This text was automatically generated on 2 February 2023.

Creative Commons - Attribution-NonCommercial-NoDerivatives 4.0 International - CC BY-NC-ND 4.0 https://creativecommons.org/licenses/by-nc-nd/4.0/ 


\section{Nathan Lyons: In Pursuit of Magic at the George Eastman Museum (Rochester, NY), retrospective or exhibition?}

The exhibition Nathan Lyons: In Pursuit of Magic at the George Eastman Museum, January 25 - June 9, 2019

\section{Bruno Chalifour}

1 Some two years after Nathan Lyons's passing-away on August 30 2016, the George Eastman Museum (GEM) is presenting an overview of the lifetime work of one of the central influencers of American photography in the second half of the XX ${ }^{\text {th }}$ century : a photographer exhibited in the most prestigious museums since 1960 (MoMA), a curator, an editor, an educator, an assistant director at the George Eastman House, a founder of Visual Studies Workshop and its international magazine Afterimage, an instigator and co-founder of the Society for Photographic Education,... just to list a few of his many activities in and for photography. The idea for In Pursuit of Magic germinated in 2013 and started as a collaboration between the photographer and the assistant curator at the GEM, Jamie Allen. The latter had to take over the whole project in 2016 helped by Lyons's spouse, Joan, and the GEM chief curator, Lisa Hostetler. As a result, the exhibition in its final form oscillates between retrospective and first exhibition of the photographer's recent foray into digital color photography, between didactic homage and sometimes puzzling experimentation.

\section{Nathan Lyons, a life in photography}

Nathan Lyons was born in New York City in 1930. After two years in the US army in Korea as a photographer, he enrolled at Alfred University (NY) and graduated in 1957 with a BA in literature. During this period he had taken art classes including photography with John Wood. Wood had studied at the Chicago Art Institute (also 
known then as the New Bauhaus following Moholy-Nagy's role in its creation) under Harry Callahan and Aaron Siskind. Wood had a strong impact on Lyons who, as a result, decided to go to Chicago. En route he stopped in Rochester to meet Minor White who had just left the George Eastman House to join the faculty of the Rochester Institute of Technology. White informed Lyons that Beaumont Newhall, the then director of the museum, was looking for someone to replace him. This is how Nathan Lyons became part of the staff, ending his function as an assistant director in 1969 when he "was resigned" by a museum board too conservative for his ideas. In his twelve years at the GEM, Lyons had curated several key exhibitions championing a growing renewal in American photography with Photography'63, '64, and '65, The Persistence of Vison (1967), Vision and Expression (1969) as well as Lee Friedlander (1963), Dave Heath (1964), Aaron Siskind (1965), the historical Contemporary Photographers Toward a Social Landscape (Bruce Davidson, Lee Friedlander, Danny Lyon, Duane Michals, and Garry Winogrand) in 1966 and Photography in the Twentieth Century for the National Gallery of Canada (1967). He developed numerous educational programs, instigating the foundation of the Society for Photographic Education (1962), and Oracle (a yearly symposium for historians and curators in photography) in 1983. During his tenure at the museum, he developed sets of transparencies from the museum archives for schools and universities, creating a book-bus that would lend photo-books to educators, publishing catalogues and essays among which Photographers on Photography (1966), a compilation of seminal texts on photography. As soon as he left the museum, Lyons founded Visual Studies Workshop, an alternative structure offering an MFA program, workshops, a gallery, a magazine (Afterimage, 1972-2018), a research center with one of the best collections of artist's books in the country, and a publishing company. From the early 1960s to the late 1980s his impact on the medium did more than equal John Szarkowski's at MoMA : Lyons also taught numerous now well-respected photographers, educators and curators (Paul Berger, Charles Desmarais, William Edwards (Light Impressions), David Freund, Charles Hagen, William Jenkins, Mark Klett, Alan Klotz (gallery), Catherine Lord, Ellen Manchester, Gary Metz Anne Tucker, Henry Wessel, Cynthia Young (ICP),...). His writings on the medium include considerations on the snapshot, the social landscape, photography and the picture experience, the photographic sequence and visual literacy. ${ }^{1}$

\section{Nathan Lyons photographer}

3 The vast majority of Nathan Lyons's lifework from the 1950s to the early 2000s, is in black and white analog photography. In the early 1960s, he shifted from medium and large format to $35 \mathrm{~mm}$. As shown in In Pursuit of Magic, his photography belongs to the American tradition of the "fine print" with its deep blacks and subtle grays.

4 The exhibition begins with a few large-format photographs from the late 1950s exemplifying his close relationship with Minor White, Walter Chappell and Aaron Siskind. Introducing the visitor to Lyons's philosophy present throughout the exhibition, on the wall facing the entrance of In Pursuit of Magic is a quote by Lyons extracted from Under the Sun (1960), a book-catalog published jointly with Walter Chappell, and Syl Labrot: "The eye and the camera see more than the mind knows." 2 The first two short walls starting the exhibition (on the visitor's right in the first gallery) are thence dedicated to the somewhat formal, sometimes abstract, phase of the 
photographer's work although only three abstract photographs from Under the Sun, the photographer's first major sequence and publication, are displayed. The rest of the gallery and of the exhibition is dedicated to a question that will preoccupy him during the following decades: a reflection on the urban social landscape seen from the sidewalk. In doing so, he established a sub-specialty of street photography focusing on the cultural vernacular signs, graffiti, murals, spontaneous ads, telescoping objects displayed in store-windows that most of us overlook when we drive. Lyons became then a witty detail-oriented flâneur gleaning visual evidences, "trouvailles", of contemporary vernacular culture, in line with his advocating for "snapshots" as serious sources of inspirations for the artist. Beyond Atget considered as a visual precursor, Lyons also found inspiration in the writings of J.B. Jackson on the vernacular landscape, as well as in the photography of Lee Friedlander and, above all, of Robert Frank.

Frank's seminal photo-book, The Americans (1959) plays a considerable role in Nathan Lyons's photography and teachings. Beyond the single photograph, it is the source of his considerations and theories on the organization and presentation of photographs as groups whose meaning is superior to the sum of its components. From the close study of The Americans, he develops his own practice and theory which he connects with the broader concept of "visual literacy", developing a whole self-sufficient visual language completely different from our spoken and written language. As a testimony of this approach, none of his books, from Notations in Passing (1974), to Riding First Class on the Titanic (1999), After 9/11 (2003), and Return Your Mind to Its Upright Position (2014) rely on text. They all display groups of black and white $35 \mathrm{~mm}$ photographs separated by a blank page and usually starting with a similar subject and composition that will be repeated and declined at the beginning of each group, in the same way as Frank used the American flag as punctuation in his "sad poem sucked out of America." ${ }^{3}$ The rest of the group is composed of two facing images (diptychs), one on each page, with which the author creates a dialogue, generating meaning beyond the single image, investigating the possibilities of the "extended frame." Nathan Lyons's books, in their whole, should be considered as a long sequence whose meaning relies on their addition. They create a single long sequence illustrating the evolution of Nathan Lyons's style as well as his more and more expressed political positioning. In fact the four books mentioned above could be joined (and exhibited as such) defining an earnest and witty life-long flânerie, exhibiting their author's preoccupations and their evolution as well as the progressive sophistication of his style.

In Pursuit of Magic at the GEM celebrates Lyons's sequenced books of black and white photographs dedicating wall space to the images composing them in the first gallery and at the beginning of the second one (roughly one wall). To compensate for the lack of wall-space for such an endeavor as a retrospective of his lifetime work, the curators have thoughtfully displayed each book at the beginning of each book-sequence. They are free-standing and can be easily perused by the curious visitor. Such a solution is unfortunately not without generating problems. The visit of the first gallery flows from right to left, a movement that the curators justify by the combined geography of the room and the visitors' apparent and observed sheepish progression from room to room, through previous exhibitions. This happens to be counter to our reading movement and interferes with the sequencing of photographs and their understanding. The selection of photographs operated by the curators and their display are not always conducive to a real grasp, not to mention legibility, of the photographer's style and essence. Instead, for instance, of starting, as all Notations in Passing does, with a single 
image followed by diptychs interrupted again by a space (another single image mirroring the first one) before going into more diptychs, the space dedicated to Notations starts with a diptych and only shows a single image, unrelated to any other displayed, toward its end. Because of the anticipated circulation of visitors and the sequencing on the wall that ensued, all the diptychs and their succession have to be read backwards (from right to left), which can be a little disconcerting if not utterly confusing. Another issue lies in the fact that the fundamental connection between Lyons's work and Frank's, one which, if quoted, could have helped some visitors relate to Lyons's own sequencing, is all the more lost that it is not mentioned anywhere.

7 The second gallery, about four times bigger than the first one, begins with the latest sequenced books, still in black and white, by Lyons (After 9/11 and Return Your Mind [...]). These roughly occupy one third to one quarter of the space which is otherwise dedicated to the photographer's recent foray into digital color photography. This second gallery also comprises two panels of six black and white diptychs taken in Mexico whose only connection to the rest seems to be an illustration of the word "diptych" finally defined on the wall next to them... this after the visitor has been exposed to at least four scores of diptychs. Puzzling choice, all the more as these were never part of any book or group of photographs sequenced by the photographer!. We then enter a vast space in the gallery (including three of its walls) dedicated to ninetyone color photographs taken by the photographer in the last ten years of his life. Lyons's project with his color work was never finalized, which means he did not have the time to select them, sequence them, and even print them all. It had been his goal to only show this new work in this exhibition. Unfortunately, again, because of Lyon's death in 2016, the selection and display (we cannot speak of any sequencing here as his would have been impossible to invent) were left to a young curator informed by her conversation with the photographer and subsequent ones with his wife, Joan, a celebrated printmaker and book artist. As the reader may have guessed at this point, the result is disappointing because missing the essential elements of Lyons's photography: selection and sequencing. It is a compromise resulting from the difficulty of handling complex (and somewhat problematic in its use of color) work without the author's supervision. However the usual subjects of his photographs are there: road signage, murals, graffiti, store windows, spontaneous irritations or celebrations written on walls or sidewalks to which a new element has been added, and with which it sometimes interfere, color.

\section{Nathan Lyons in pursuit of color}

8 The central issue that this recent development of Nathan Lyons's photography raises is that of color photography, and the lifelong use of black and white suddenly veering off to color, and not just color, digital color which involves a new knowledge and practice. One cannot suddenly steer a motorboat the way one used to steer a sail-boat! Interestingly, in a 2007 conversation with Rick Hock and Carl Chiarenza published in the spring issue of Image (George Eastman Museum), Lyons declared: "I think many photographers working in black and white had to learn how to control their medium; today any digital photographer is going to have to learn how to control the medium as well. That's part of the responsibility in being an image-maker. There were endless numbers of poorly-rendered prints made in black and white. We saw the same thing in 
the evolution of color processes. It made a world of difference if you were really on target with the print. As Carl [Chiarenza] alluded to, if the color was off, it was a distraction." [p. 6]

During the first stage of the creation of the exhibition (2013-2016), while he was experimenting with digital color photography, Nathan Lyons was in his eighties. He then underwent several serious health alert including heart-surgeries, and does not seem to have had the time to acquire the necessary control and mastery of this new medium, the control that he was advocating in 2007. Some of these color photographs were printed posthumously by a former student and friend who tried to do his best but here again without the photographer's supervision. The results, the prints displayed at the GEM, give evidence of a lack of technical control ranging from color saturation to white balance affecting both camera and printer work. A blue tint has a tendency to dominate several prints, among which the one displaying "In Pursuit of Magic", especially the ones taken of walls or sidewalks. Some colors, especially the greens, just shout out of their frames reminding the visitor of badly processed and over-saturated Fuji Velvia transparencies. The blue cast over the green of some trees and lawns make them look utterly artificial as if in plastic. In many instances Lyons used color as an effective added element in his photographs. One clear example is the photograph "Untitled" that I would call "Angel/Devil" where, in spite of the usual slight blue cast visible next to the slight orange of the texture of the two wings (better visible once the blue cast has been corrected) and the red of a devil's horns and tail are crucial to the dynamic of the image. So if color adds impact, and meaning, expands the esthetic qualities of the photographer's art to a new sphere in many cases, in others its becomes a distraction when it is not utterly detrimental. Color definitely impacts the consistency and coherence of the whole body of work, two areas that were some of Lyons's most obvious strengths.

\section{New can be the enemy of well}

10 What can be said, as a conclusion, of this exhibition and its catalog? ${ }^{4}$ First they do constitute interesting documents, a first-hand and first-aid testimony for the visitor wanting to discover a major œuvre by a great visionary of the second half of the twentieth century. Novice, student, museum-goer or photographer, all will benefit from it. The catalog should not be missed as it adds an extremely well documented biographical essay by Jessica McDonald to the exhibition, an excellent choice by the two curators of the show. ${ }^{5}$ However, both the exhibition and its catalog suffer from being compromises between a retrospective and the first presentation of a body of work in progress. Both would require more space for such an abundance of photographs. This project illustrates another interesting point: it can be problematic to show new work in progress, all the more while not totally mastering a new technique. Under such conditions the absence of the author renders the task almost impossible for the ones left to carry it to its completion. Both exhibition and catalog have been expected, all the more three years after Nathan Lyons's final going out-of-focus. They could have been historical landmarks generated under exceptional circumstances: the cross vision of a renowned artist, a local, national, even international celebrity, at the very end of his career (with all the perspective and wisdom that are associated with this stage) with a curator from a totally different generation. Obviously the 
photographer's goal was different, probably biased by a survival instinct that pushed him to ignore hurdles that he had clearly identified in others, in other times, as enounced in 2007. The responsibility of the color work fell upon a young curator, specialized in conservation and not so much in the esthetics and philosophy of photography, in the complex issues Lyons questioned all his life. Her respect of the photographer's choice accounts for the size of a group of color photographs somewhat inconsistent with the artistic rigor and the coherence displayed in the preceding bodies of work in black and white. Another example, for I who had known Nathan Lyons for thirty years, is the choice of the title of the show, which did not have the humor and the relevance, the decalage, of the other titles. From all the photographs that he took for a period of over fifty years, the pursuit that emerges is not that of magic but that of meaning, of a humanistic and understanding relationship with our environment and mostly with our fellow human beings. His photography has been a constant questioning of our values, our aspirations, our frustrations, and our culture, always expressed through his visual language of choice, photography.

\# 01: Nathan Lyons, Untitled (New York City, 2013)

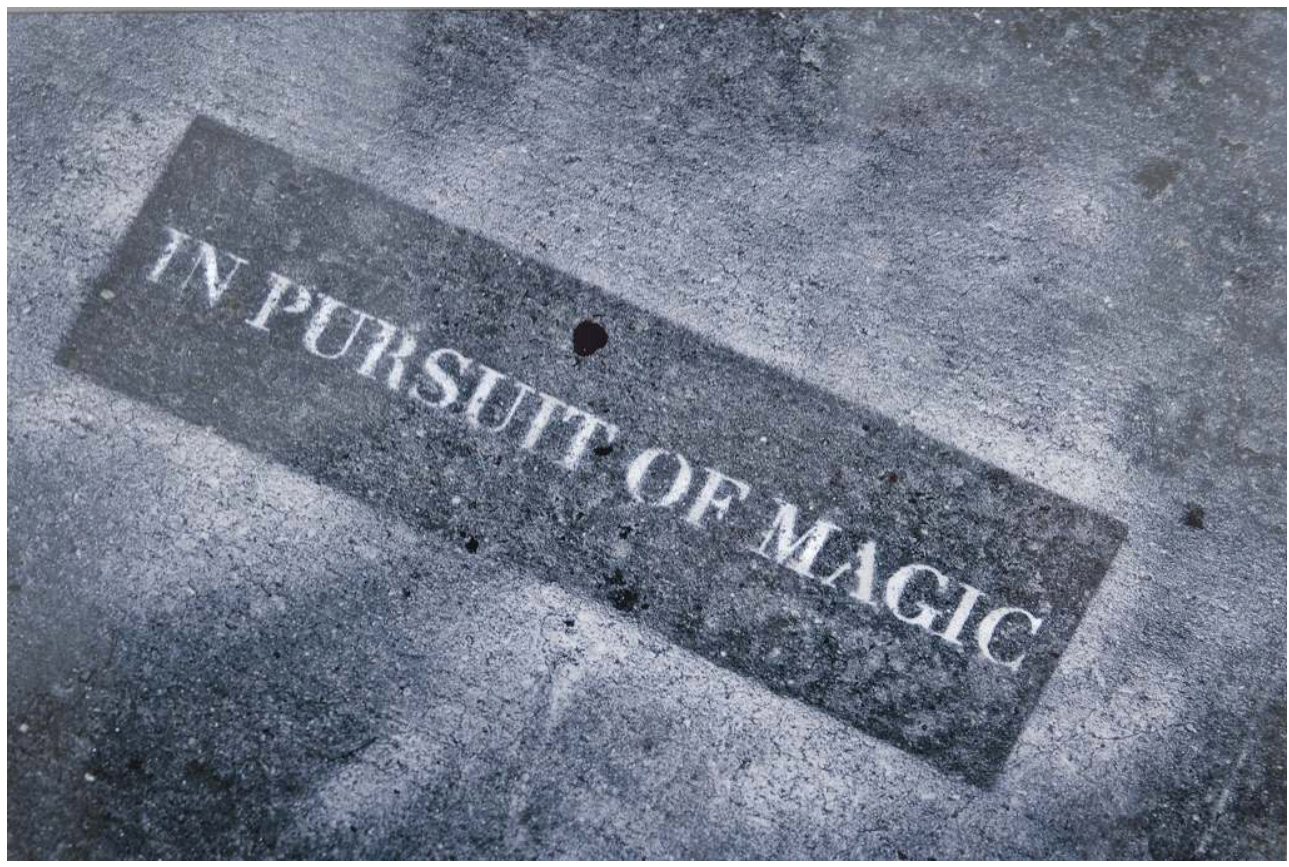

This photograph, which gave its title to the exhibition (a title chosen by Nathan Lyons himself in 2013), although very monochromatic, is in fact a digital color image. The message is simple and poetic in what it evocates, almost a street haiku. By its simplicity and standing as a testimony of spontaneous street expression, it echoes some of the early photographs of Notations in Passing (1974). This title is quite puzzling in the sense that if the photographer had been seeking anything throughout his life and teaching, it was definitively more meaning than magic. This yearning for "magic" might have been the expression of a search for an antidote to the disillusion experienced during the eight years of G.W. Bush's presidency (as often visually expressed by the photographer in the pages of After 9/11 (2003) and Return Your Mind to Its Upright Position (2014)).

(c) Estate of Nathan Lyons, courtesy of the George Eastman Museum 


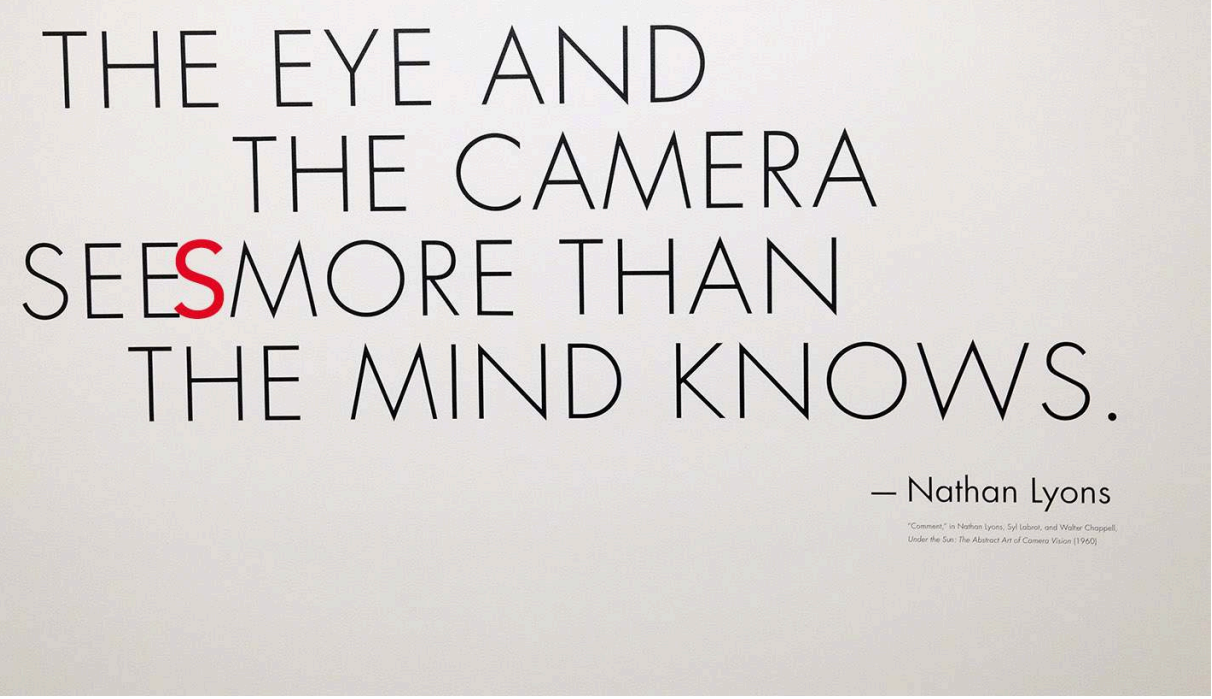

As mentioned in the text of this review, the original quote concluding Lyons's essay in Under the Sun (1960) read this now famous aphorism "The eye and the camera sees more than the mind knows." "See" was spelt with an ending "S", typo or implying that, through "camera work", the photographer can reach beyond reality - attaining the truth that Edward Weston or Alfred Stieglitz thought it could unveil (epiphany / alèthéia)? The "corrected" version of the quotation on the wall of the George Eastman Museum (without the red " $S$ " added by the author) betrays the ethical principle of a quotation and might be going further in ignoring the meaning of that figure of speech used by Lyons, one that would be in line with Minor White's ways of expressing the transcendental / esoteric nature of "camera work": the eye and the camera must be so united in the photographic process as to be one.

(c) Bruno Chalifour, 2019 
\# 03: Cover of the book Under the Sun. The Abstract Art of Camera Vision (1960)

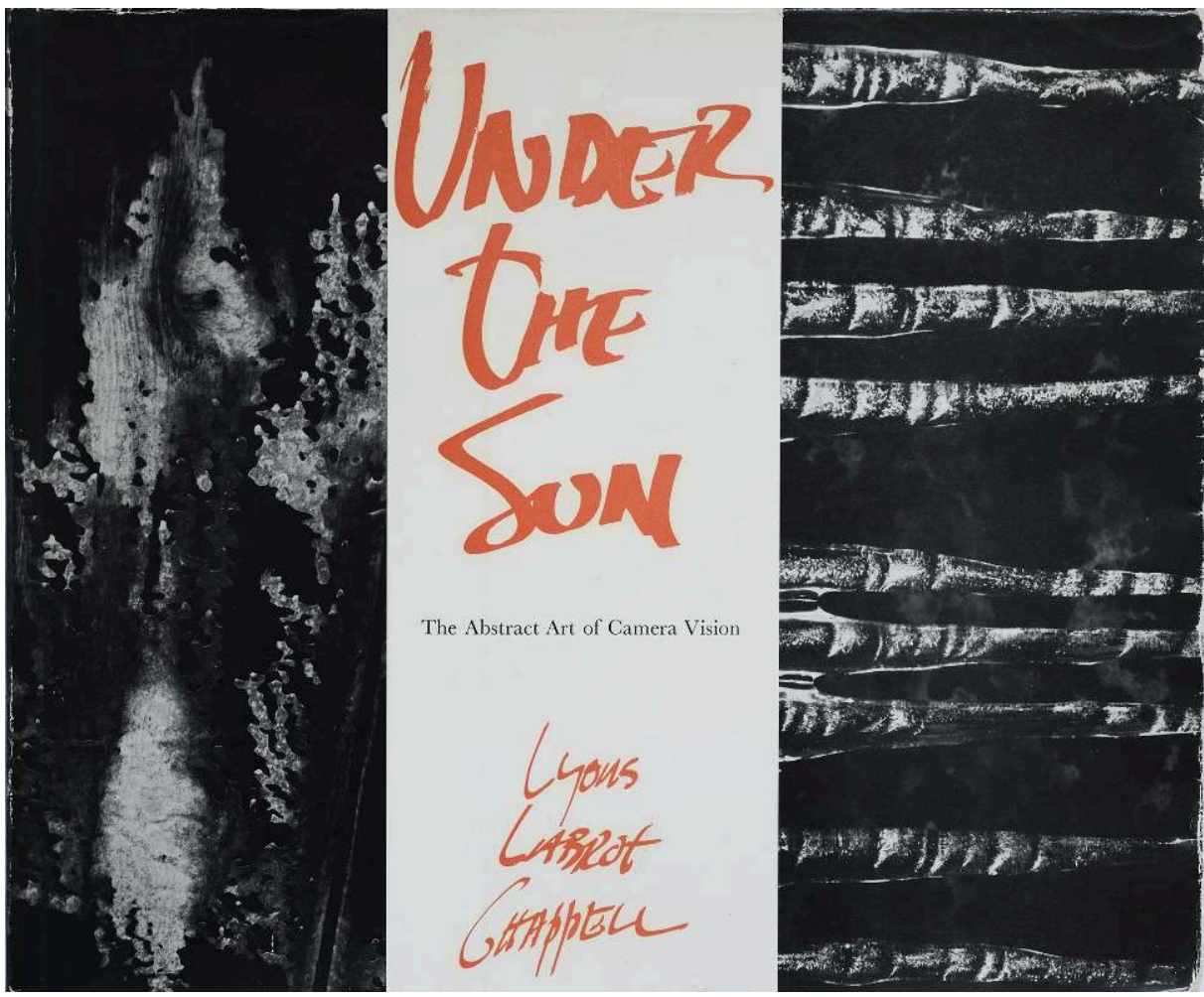

Cover of the book Under the Sun. The Abstract Art of Camera Vision (1960), co-edited and published with Syl Labrot and Walter Chappell. Chappell was extremely close to Minor White and introduced him to the philosophy of George Gurdjieff (1866 - 1949), an approach to the world that was very influential in White's own philosophy of photography and which, as a result, left a mark on his students. [see http:// rochestergurdjieffcenter.org for more details]. In Under the Sun Chappell describes "camera work": "The camera allows me to arrest my vision as a realization in outer space, precisely at that moment when my understanding and conscience intuitively experience a reality most important for my awareness of Life's essential presence. [...] The art of creative work in any medium is, for me personally, the struggle to unify my discovery of Nature with the growing discovery of my inner being."

(c) Bruno Chalifour, 2019 
\# 04: “Untitled (1959)"

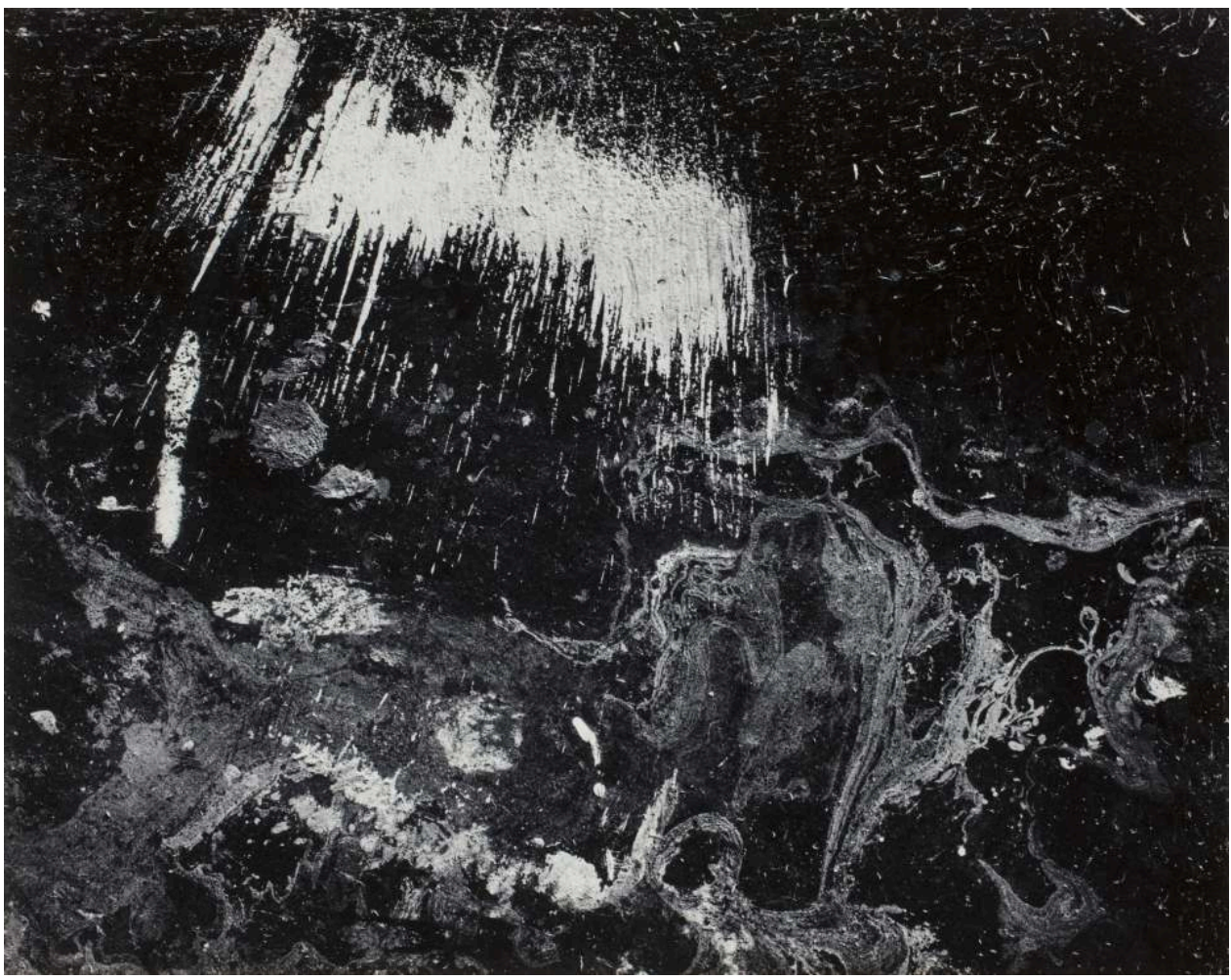

This "abstract" photograph by Nathan Lyons is part of the series ("sequence" in Lyons language) included in Under the Sun. Rather than "abstract", it represents something real that exists in front of the camera which decontextualized it from the real world by the framing operated by the photographer. As a consequence the later more "concrete" photographs of Notations in Passing can also be considered as abstraction as they follow the same protocol. Some of the photographs of Under the Sun were shown at MoMA in New York as part of The Sense of Abstraction (17 Feb. - 10 April, 1960) organized by Edward Steichen. In this exhibition, the Minor White "crew", very present in the pages of the magazine Aperture whose editor was White himself, consisted of P. Caponigro (7 prints), W. Chappell (3), C. Chiarenza (4), S. Labrot (7), N. Lyons (6), M. White (8). By not giving titles to his photographs Lyons is already asserting his goal to consider images as a (visual) language, separated from the written and spoken ones, with its own vocabulary and syntax. The book and the MoMA exhibition will be the climaxes of Lyons's "Minor White phase" and of his investigation of "the landscape of the mind" (a concept developed by his friend and colleague Carl Chiarenza). His encounters with Robert Frank's seminal work, The Americans (1959) and with Lee Friedlander whose work he will show at the George Eastman House in 1963 (before John Szarkowski at MoMA) will convince him to take his photography in a new direction, that of "the social landscape" (a phrase coined by Lee Friedlander in an interview published in Contemporary Photographer [for more on this and both concepts (landscapes of the mind and the social landscape) see Bruno Chalifour "Le paysage de la photographie américaine de paysage, 1960-1990", doctoral dissertation, Université Lyon 2 - Louis Lumière, Oct. 2019]. It appears as plate X in Under the Sun and is typical of what we could call the Minor White / Water Chappell phase in Nathan Lyons's career. This period was a short one, 5 years at the most, between the time the photographer stopped in Rochester on the way from Alfred University where he had just graduated with a BA in creative writing to Chicago. Had not Minor White and Beaumont Newhall offered him a job at the George Eastman House, the modern history of American photography would be quite different. Once in Rochester Lyons became part of the group of young photographers that regularly met at Minor White's home around White and Chappell. This type of imagery was mostly achieved through close-up views of objects, most of the time entropic surfaces resembling Rochach tests (without their symmetries). The general tonality is dark; the photographers took full advantage of the high content in silver of the photographic papers of the time. They photographed things not so much for what they were but "for what else they might be" (M. White), drawing on the theory of the "Equivalent" articulated in the late 1920s by Alfred Stieglitz. These photographs are metaphoric tools also conceived to generate contemplation and meditation.

(c) Estate of Nathan Lyons, courtesy of the George Eastman Museum 


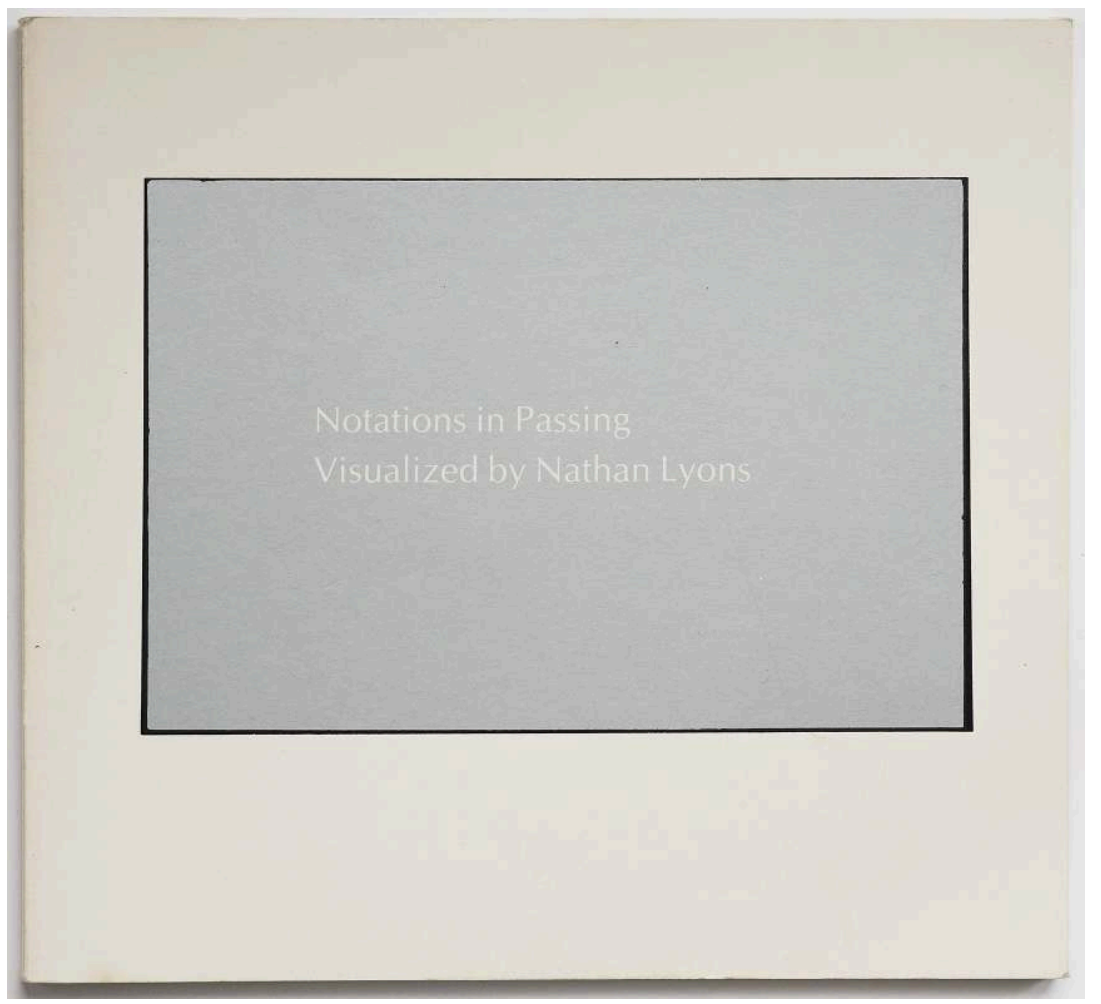

The book is composed of 96 black and white photographs separated in small groups. This type of photography could belong to the genre labelled, since then, "Street photography" if it were not for the total absence of human beings. The streets, their signs and graffiti (either on the walls or on the sidewalks), their shop-windows evoke other photographs by Eugène Atget, Walker Evans, Robert Frank and Lee Friedlander. Lyons is interested in spontaneous vernacular expressions in the urban landscape, and the contradictions in American culture that his juxtapositions, either within the frame of his photographs or with two facing pages in the book, illustrate. From the beginning of the 1960s on, the photographer became the epitome of the cultural flâneur, one interested in the serendipity of meaning gleaned along the streets of America, seeking trouvailles of vernacular culture on billboards, in shop-windows, on the walls of low-income sections of American cities. From abstract artist, Lyons reinvented himself into a visual sociologist and cultural commentator. One of his theoretical references is J.B. Jackson's writings on the "vernacular landscape." In Notations in Passing, Lyons resorts to white pages as punctuation and in doing so creates a more visible syntax than Frank did in The Americans. Just as Frank did in his seminal opus, Lyons groups his images by subject and interlaces them avoiding a blatant linearity. Instead of a simple arrangement, the images are shown in a more complex and sophisticated way. Moreover, their content will grow in complexity and sophistication with the years. Most of the groups of images start with the view of a blank surface in the center of the frame (for instance advertising signs devoid of any advertisement. See reproduction \# 08 and \# 09 further here). The cover of the monograph pushes this strategy to its maximum, only displaying the title in white letters against a silver-gray rectangular background of the same size as the photographs inside the book ["silver" as in silver-halide, the light sensitive salt used in photographic film and papers]. A black line surrounds the silver-gray rectangle (as it does with all photographs in the book), a homage to Cartier-Bresson's usual way to present his own images, a technique that is meant to show the spectator that nothing of the original in-camera vision / experience was later modified ("cropped"). With this book Lyons established the framework of what his photography would be until his death in 2016.

(C) Bruno Chalifour, 2019 - Courtesy of Nathan Lyons 
\# 06: A view of the wall of the exhibition dedicated to Notations in Passing

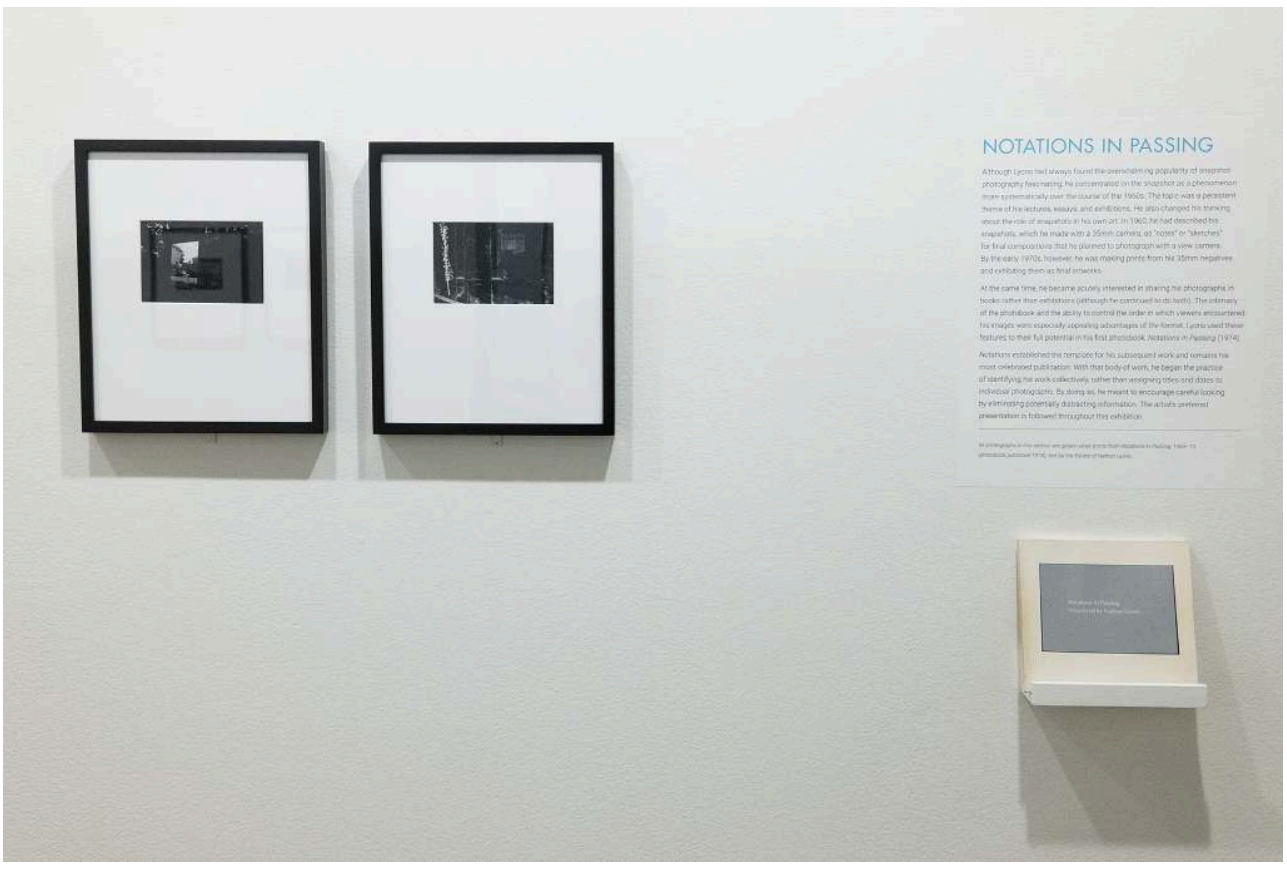

One will note that 1-not able to show every photograph of the book for lack of space the curators had the good idea to have the book displayed for public consultation; 2-the movement of the display is from right to left, the opposite of the way we read or look through a book, the opposite of the author's design. This choice is problematic regarding what constitutes one of the strengths and legacies of Lyons's lifework: sequences and series; 3-the first two images displayed on the wall are neither the first one in the book (the title-page, see below \# 07) nor the first one after the title, one accompanied by the word "introduction", that displays a blank billboard (a crucial syntactic and recurring element in the book).

(C) Bruno Chalifour, 2019

\# 07 (p. 3 in Notations in Passing): Title-page of the book showing a petroglyph (signs on a wall) in the American Southwest

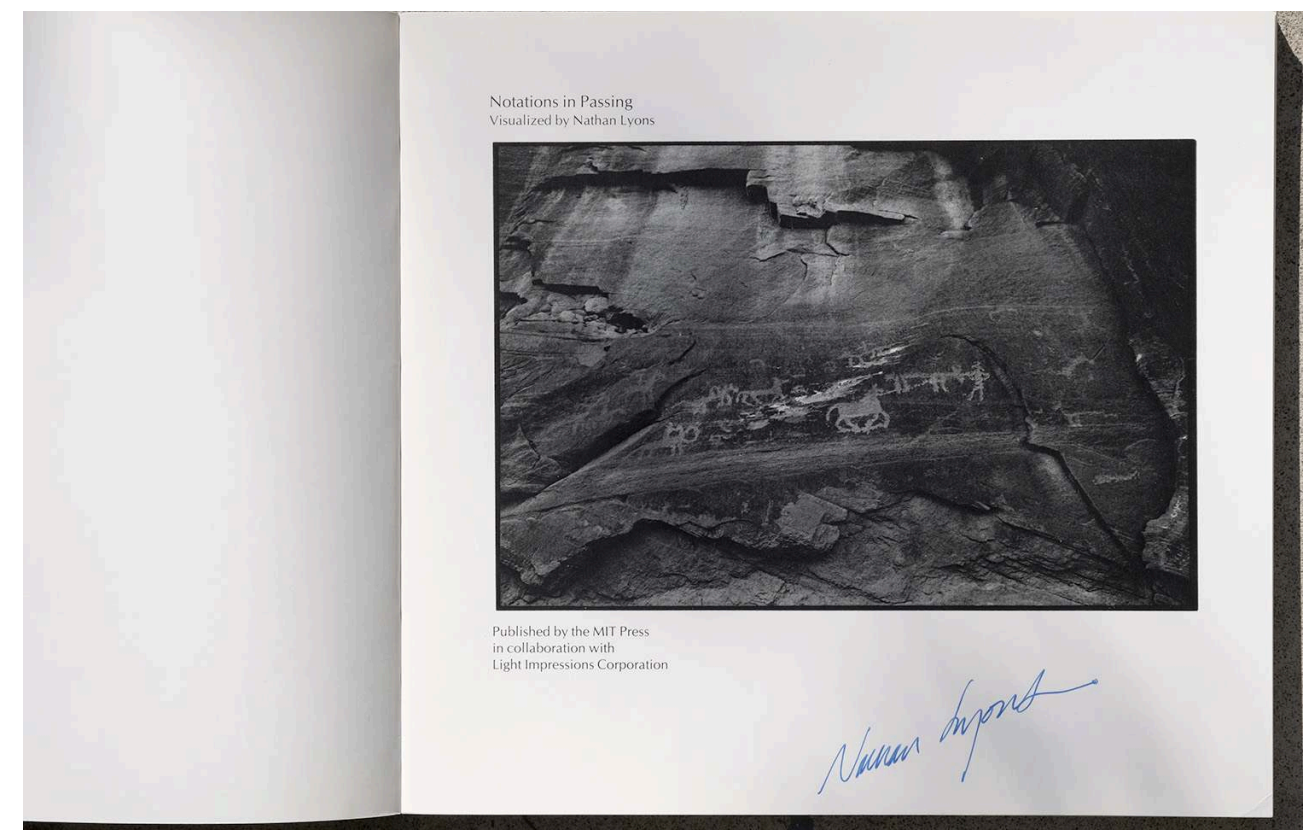

(C) Bruno Chalifour, 2019 - Courtesy of Nathan Lyons 
\# 08 (p. 20 - 21) in Notations in Passing)

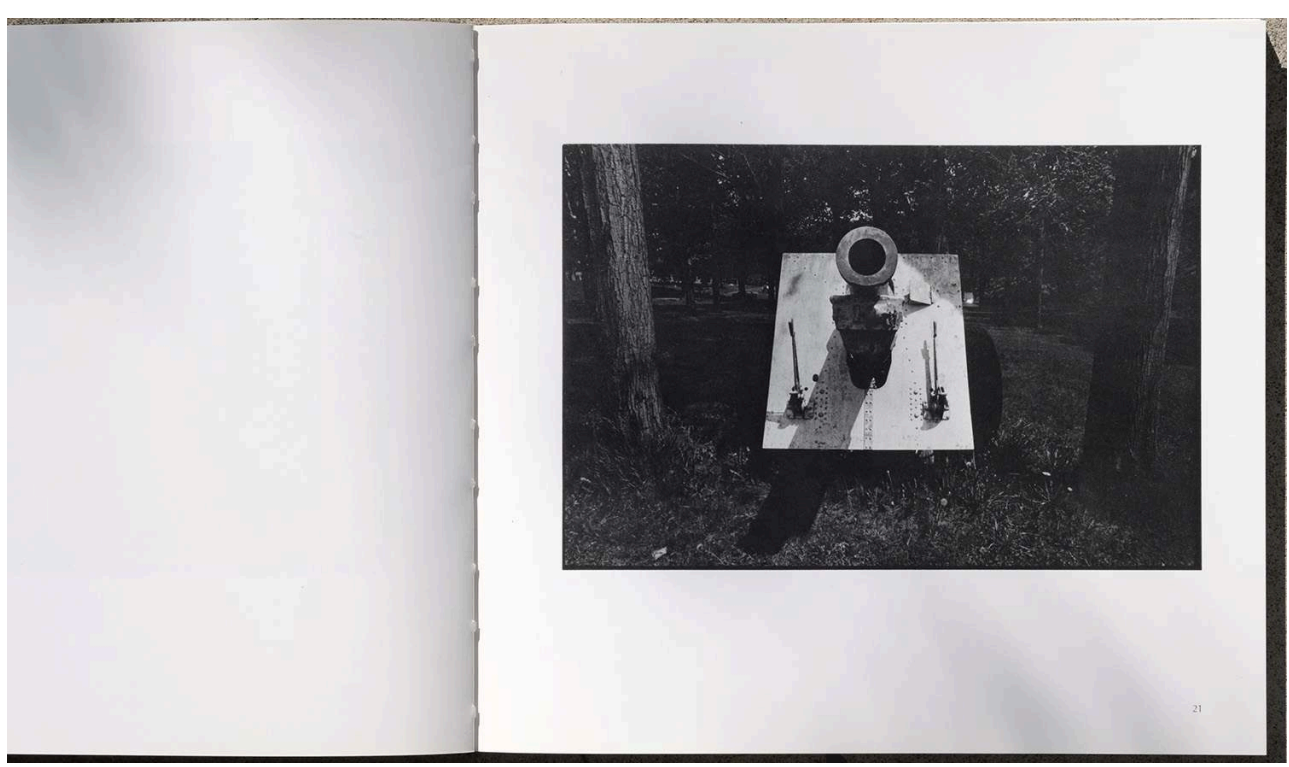

(C) Bruno Chalifour, 2019 - Courtesy of Nathan Lyons

\# 09 (p. $26-27$ in Notations in Passing)

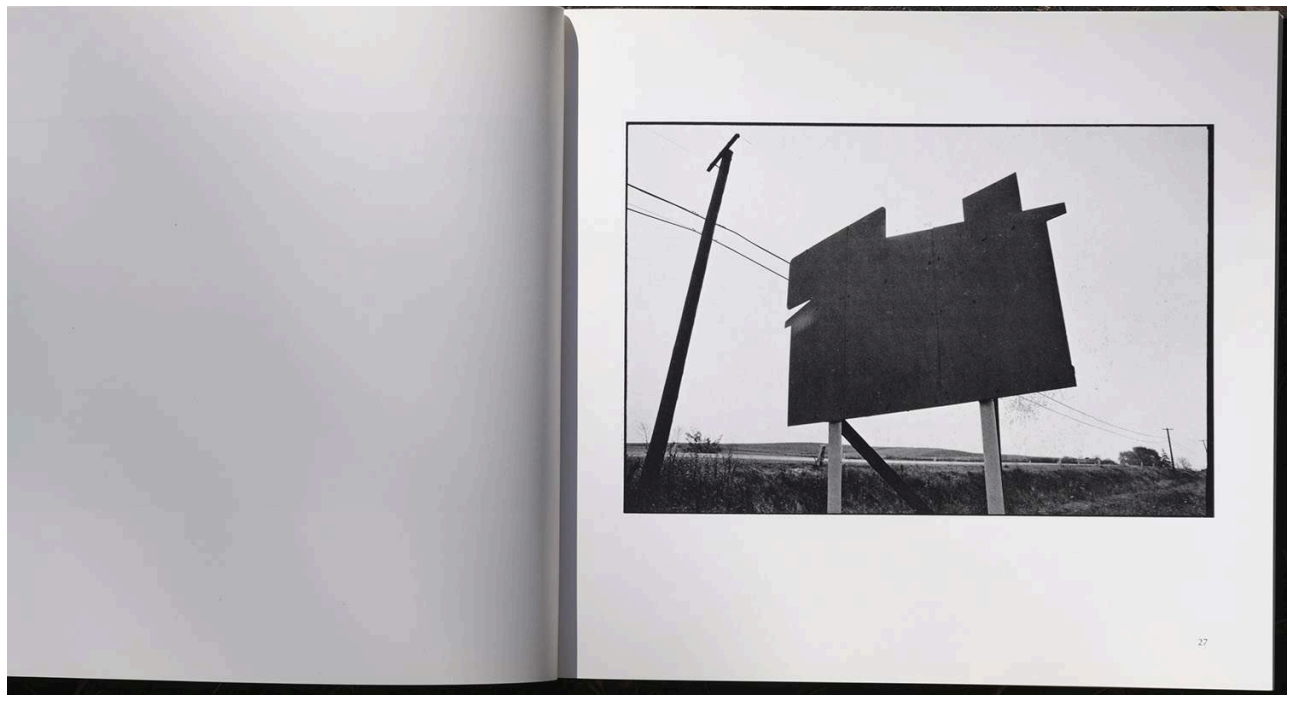

\# 08 and \# 09 are two examples of a white left page being used as punctuation, ending a specific group of images, and of a starting right page showing the photograph of a blank surface. In both cases there is a particular incongruity in these useless objects in the landscape. \# 08 constitutes a sort of visual pun, referencing American military culture and taking the readers by surprise, not meeting their expectations of a blank billboard.

(c) Bruno Chalifour, 2019 - Courtesy of Nathan Lyons 
\# 10 (p. 16 - 17) in Notations in Passing)

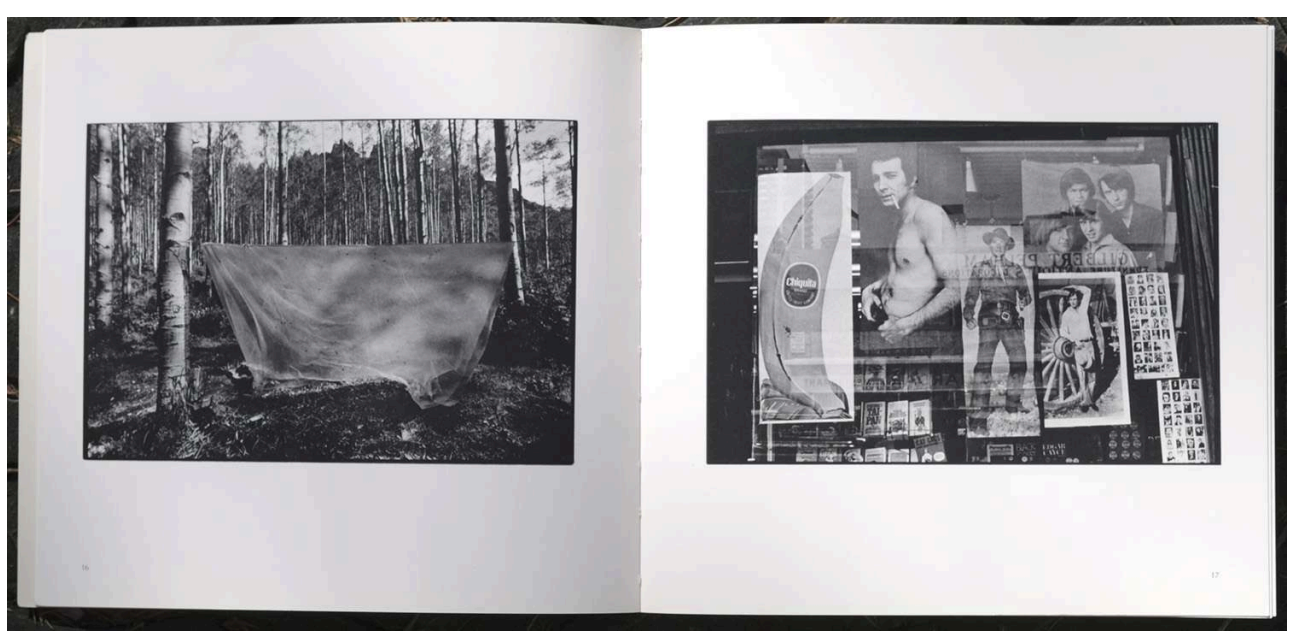

(C) Bruno Chalifour, 2019 - Courtesy of Nathan Lyons

\# 11 (p. $22-23$ in Notations in Passing)

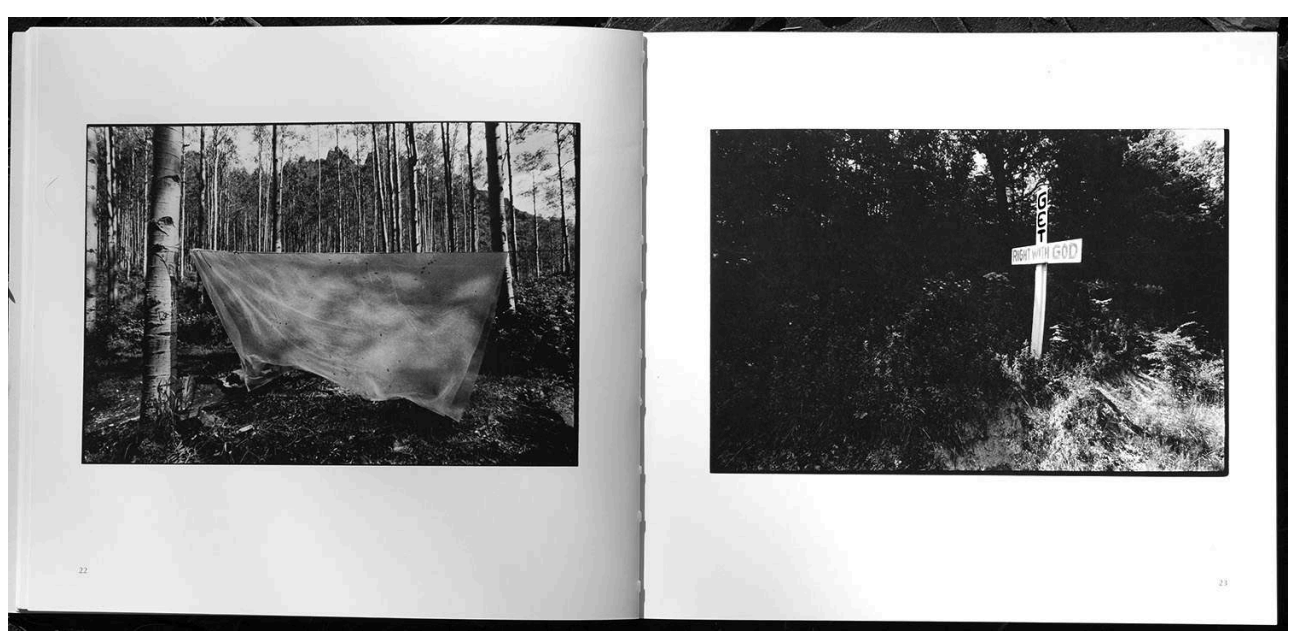

\#10 ans \# 11: another reference to Robert Frank's use of the American flag as punctuation and comment, here Lyons uses a blank sheet flapping in the wind on both left pages ( $p .16$ and p. 22). Illustration \# 10 (p. 17) constitutes an ironic reference to the American male: shirtless man with a cigarette, a cowboy, and a band picture where the four players have adopted the Beatles hair-cut, all contrasting on the right side of the frame with a Warhol-like advertisement for a Chiquita banana. Page 23 is another slanted humorous reference to Robert Franck, showing a Christian cross with the inscriptions "GET" vertically and "RIGHT WITH GOD" horizontally, an allusion to the Christian conservative, if not far-right (K.K.K.), movement in the U.S.A. (at a time when antisemitism was rampant if not blatant in the country [both Nathan Lyons and his wife Joan are Jewish]).

(c) Bruno Chalifour, 2019 - Courtesy of Nathan Lyons 
\# 12 (p. $78-79$ in Notations in Passing):

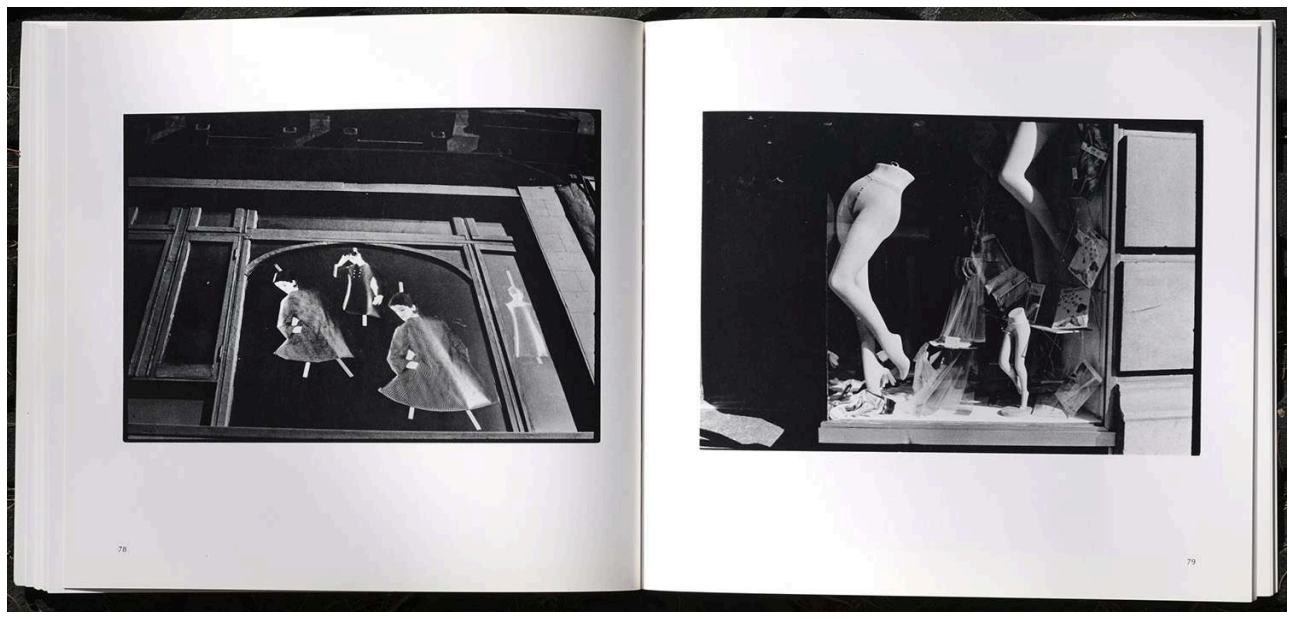

A humorous evocation of the photographs of some Paris shop-windows (showing hats, suits, corsets...) that Eugène Atget took in the first two decades of the twentieth century.

(c) Bruno Chalifour, 2019 - Courtesy of Nathan Lyons

\section{\# 13 (p. 138 - 139 in Return Your Mind to its Upright Position)}

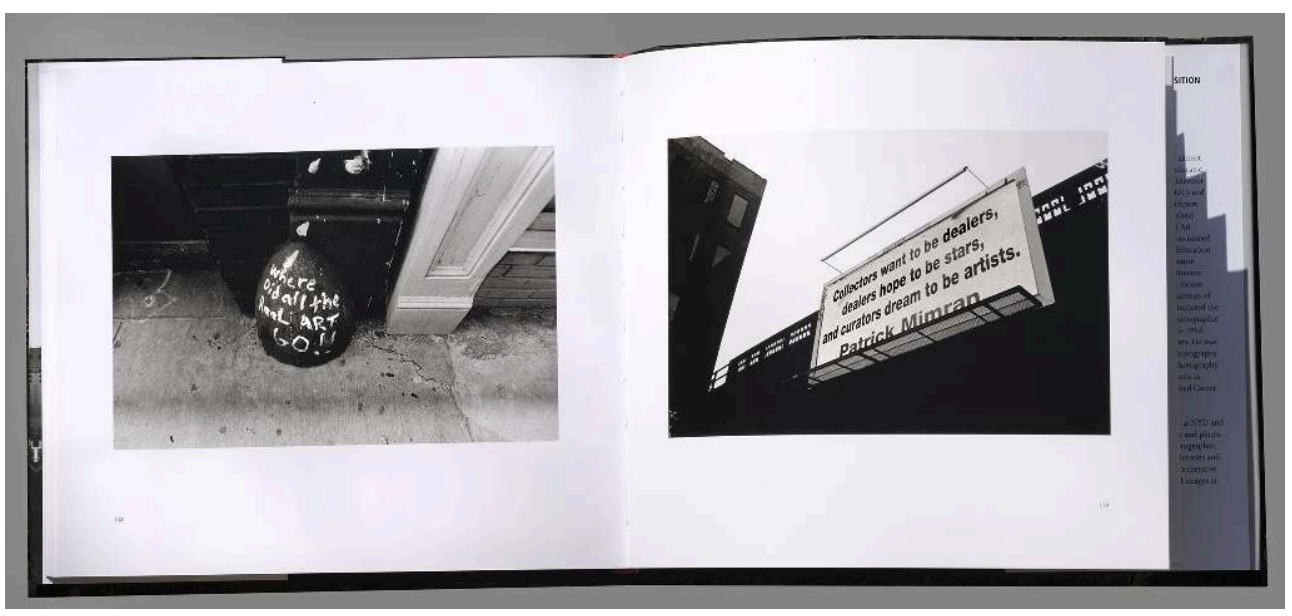

As in the preceding monograph, Riding First Class on the Titanic (1999), the photographer's work has become more political deploring the aggressive foreign policy of the U.S.A., and the perverse consequences of a money-driven society on expression, education and the arts. Page 138 reads: "Where Did all the ReaL ART GO!!", and page 139: "Collectors want to be dealers, dealers hope to be stars, and curators dream to be artists" on a big billboard hanging from what would become the High Line in Manhattan, located in what is now the gallery district (between $20^{\text {th }}$ and $30^{\text {th }}$ street, and $10^{\text {th }}$ and $11^{\text {th }}$ avenue). The billboard is part of Patrick Mimran's "Billboard Project" (Mimran, ex-Lamborghini CEO, is also a composer and a visual artist).

(c) Estate of Nathan Lyons, courtesy of the George Eastman Museum 


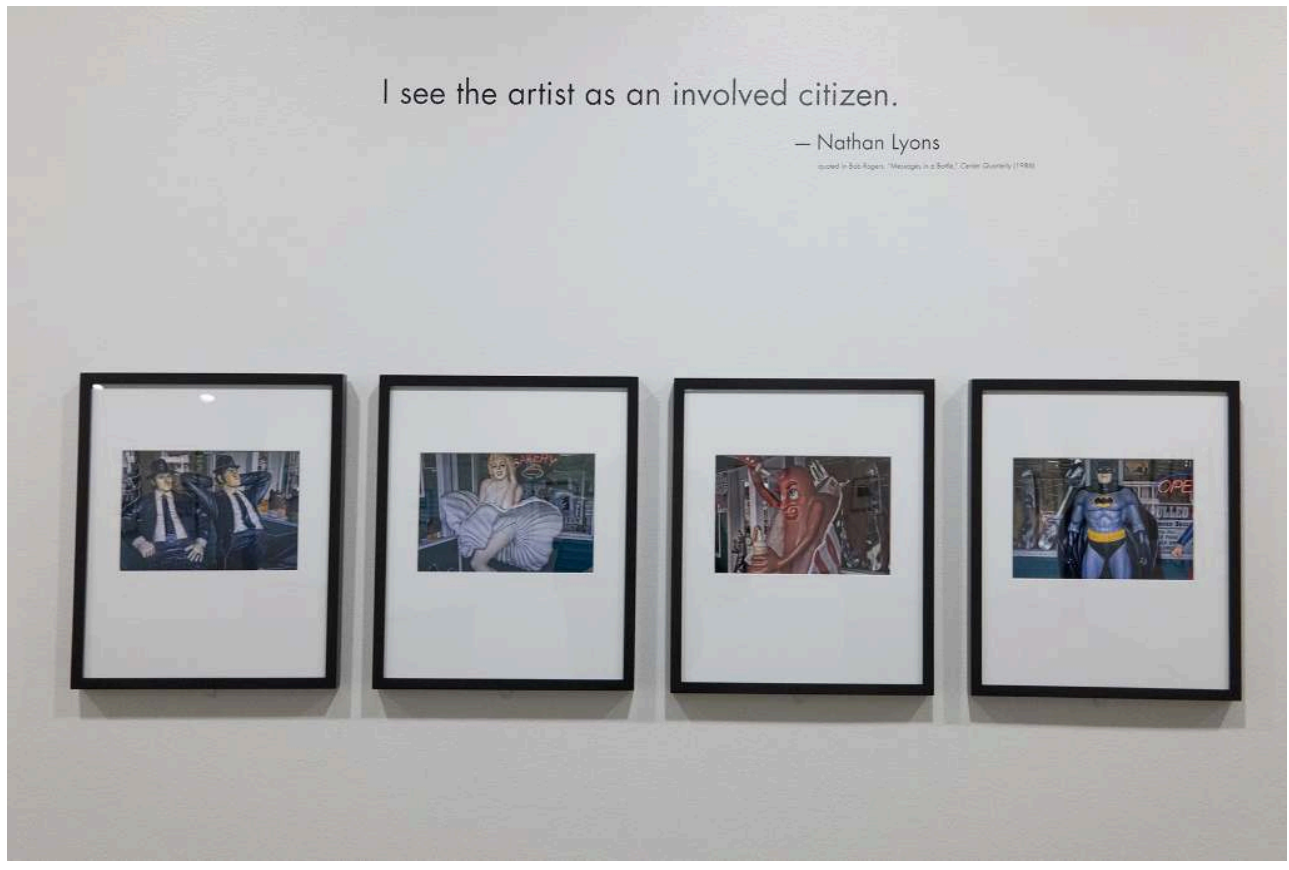

\# 15

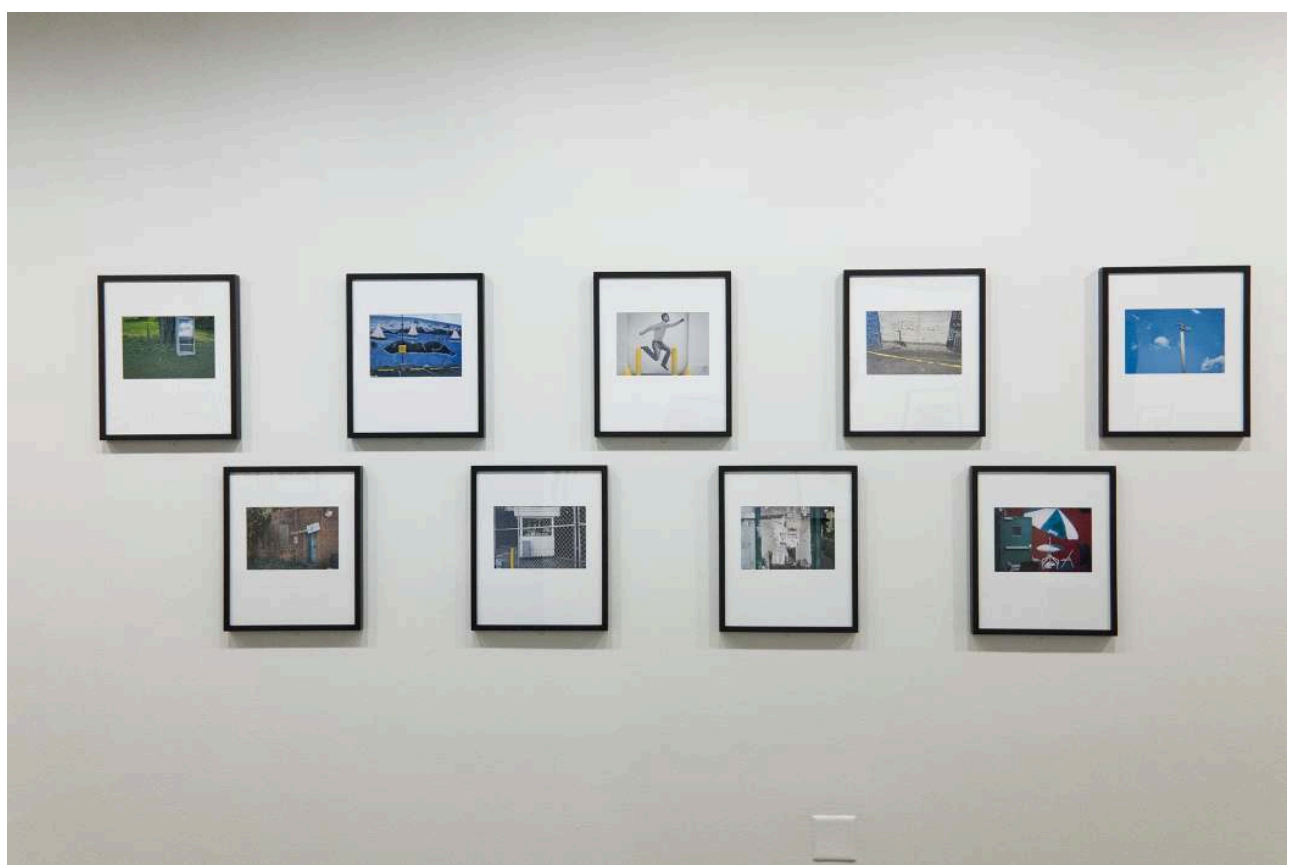

\# 14 and \# 15: The lay-out of Nathan Lyons's recent color work improvised by the two GEM curators and Joan Lyons (Nathan's wife) after the photographer's death. Both the author's famous sequencing and his book-based arrangements in diptychs are lost here, gutting the work of much of its intention and content down to a collection of sometimes amusing, sometimes puzzling color pictures, in the manner of Instagram, sometimes reducing them to colorful snapshots.

(c) Bruno Chalifour, 2019 
\# 16: Untitled (Your Name Here, 2013)

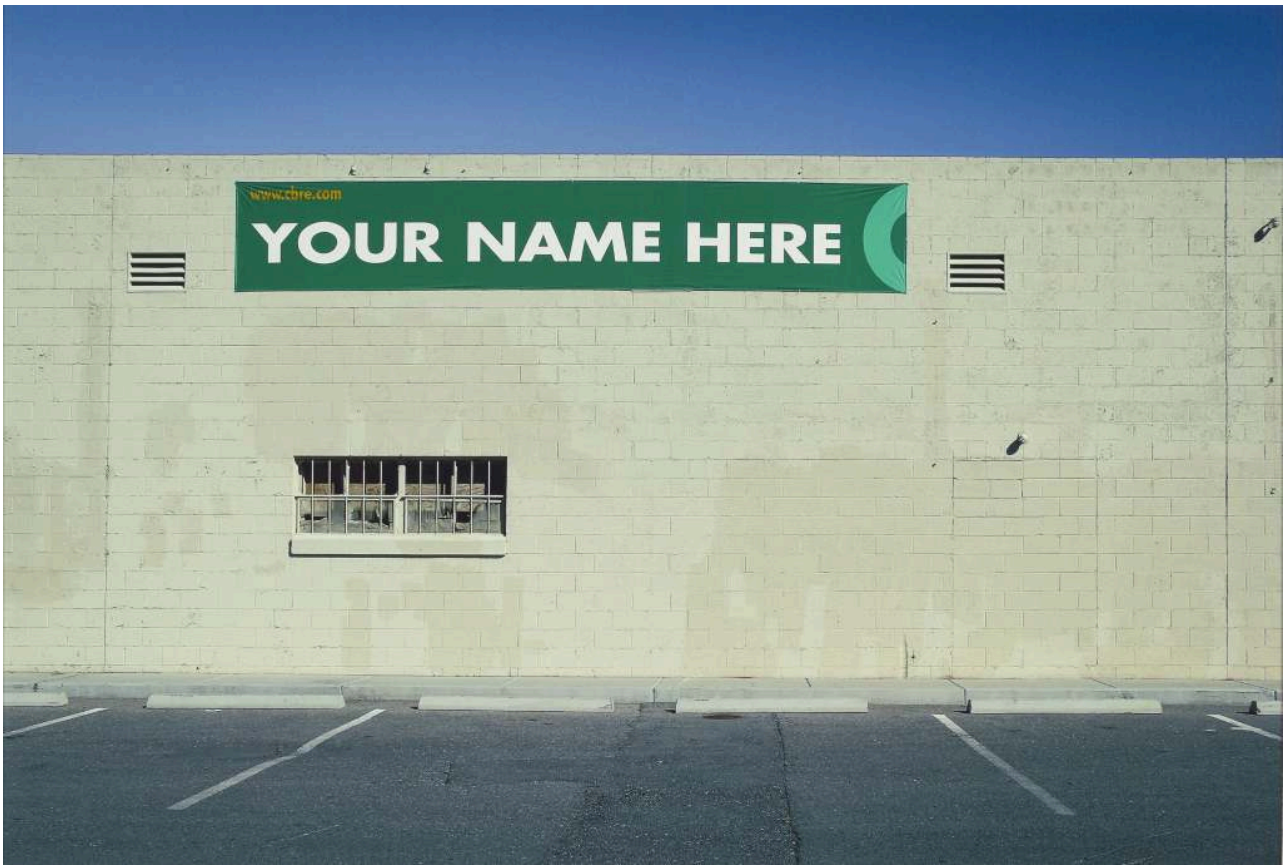

\# 16 [p.196 in catalog] is an example where color may not add much to a photograph very much in the vein of the black and white work. Also to be mentioned and noticed the fact that while Lyons was a master black and white printer he had not completely mastered digital color photography (the fact for instance, that the default settings for a camera are generally high in contrast and color saturation) and digital printing. He left the latter decisions to a printer whose choices in terms of color saturation and color balance have sometimes been arguable, many images showing a cyan-bluish cast; as a result some the greens (grass) are just shouting. [See catalog (In Pursuit of Magic, 2019) p. 192, 195, $239,257,271$.

(c) Estate of Nathan Lyons, courtesy of the George Eastman Museum 


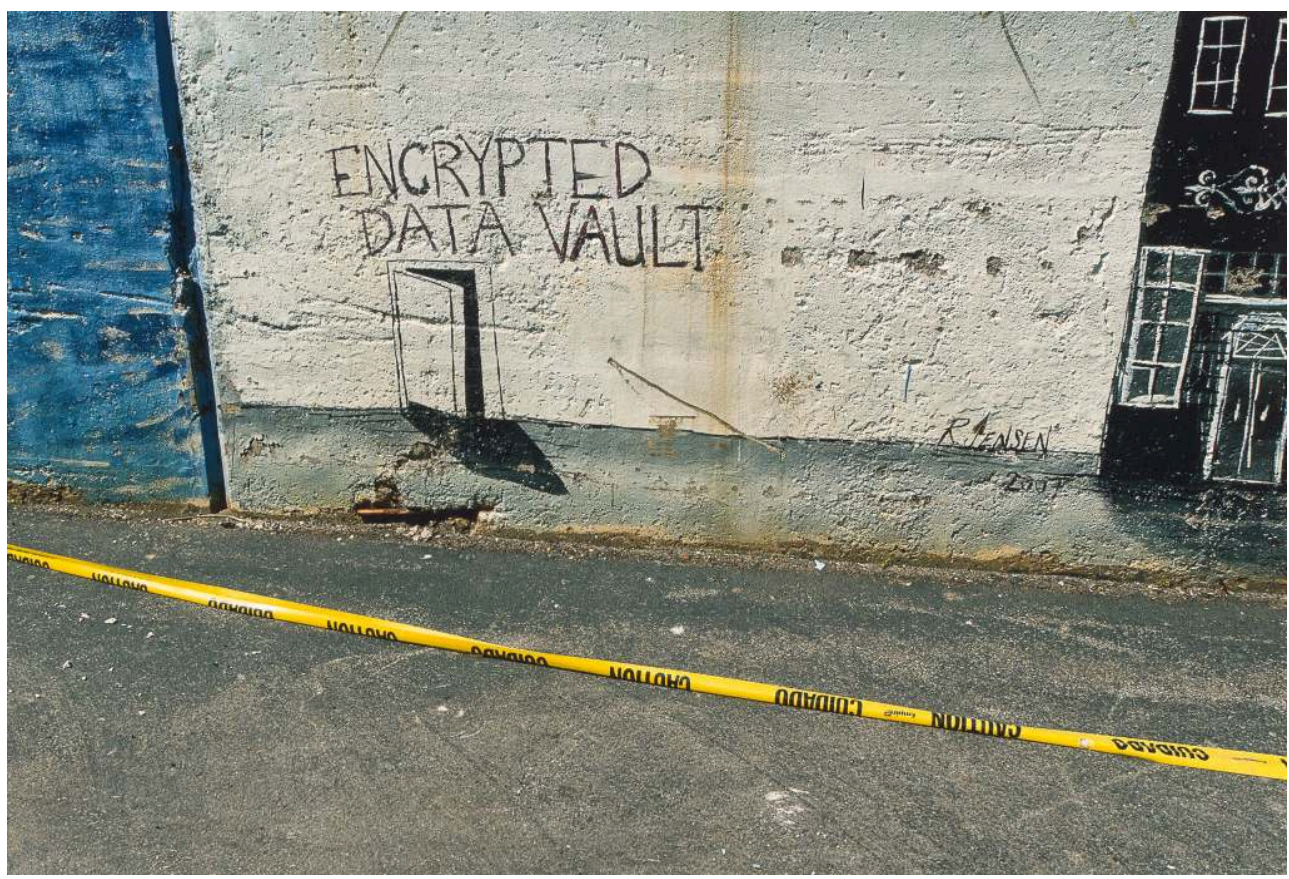

\# 17: [p. 261 in catalog] In this photograph we see the photographer's humorous comment on someone's humorous comment on digital culture, a mise-en-abîme of sorts. The color contrast between the blue of the wall in the top corner and the yellow of the "caution" tape across the frame does add to Lyons's intention, one definite example of the plus that color can bring to some photographs when it works in synergy with the content.

(c) Estate of Nathan Lyons, courtesy of the George Eastman Museum 


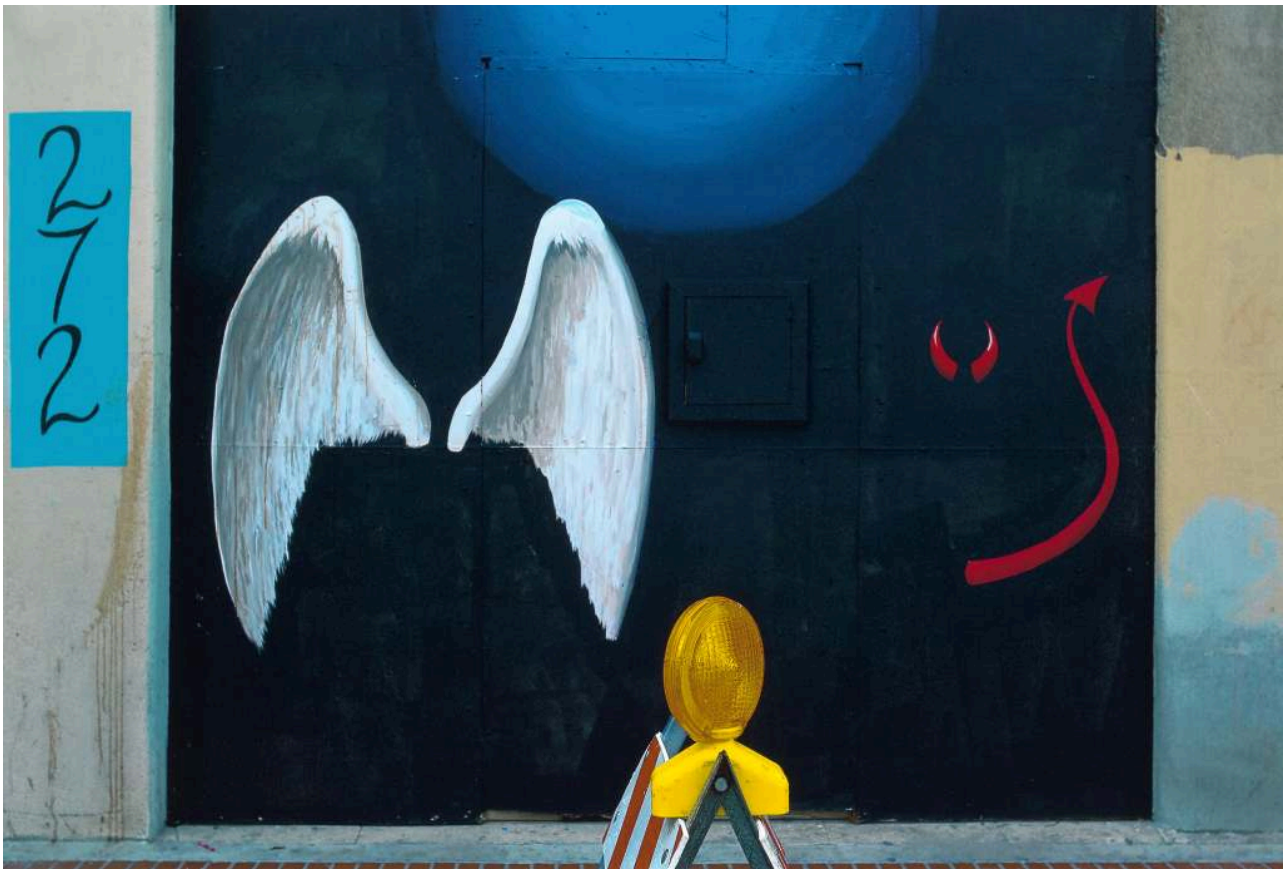

\# 18: [p. 191 in catalog] Without any doubt the most successful of Lyons's color works, even in the photographer's own eyes; a photograph that he chose to show several times in group exhibitions between 2013 and 2016. The red of the devil's horns and tail in the mural are crucial to the impact of the photograph and the legibility of its content.

(c) Estate of Nathan Lyons, courtesy of the George Eastman Museum

\section{BIBLIOGRAPHY}

Allen Jamie, Lisa Hostetler and Jessica McDonald, Nathan Lyons: In Pursuit of Magic (Rochester NY: George Eastman Museum and Austin TX: University of Texas Press, 2019).

Lyons Nathan, Labrot Syl and Walter Chappell, Under the Sun. The Abstract Art of Camera Vision (Honeoye Falls NY: Glyph Press, 1960). [Reprinted by Aperture in 1972].

Lyons Nathan, Notations in Passing (Cambridge MA: The MIT Press, 1974).

Lyons Nathan, Riding $1^{\text {st }}$ Class on the Titanic, (Andover MA: Addison Gallery, 1999).

Lyons Nathan, After 9/11 (New Haven CT: The Yale University Art Gallery, 2003).

Lyons Nathan and Marvin Bell (poems), White Out (Revere PA: Lodima Press, 2011).

Lyons Nathan, Return Your Mind to its Upright Position (Rochester NY: Artisanworks Press, 2014)

McDonald Jessica, Nathan Lyons, Selected Essays, Lectures and Interviews (Austin TX: University of Texas Press, 2012). 


\section{NOTES}

1. See Jessica McDonald, Nathan Lyons: Selected Essays, Lectures and Interviews (Austin TX: University of Texas Press, 2012).

2. In fact the actual quote is: "The eye and the camera sees more than the mind knows" as if eye+camera $=1$.

3. Jack Kerouac in the introduction of The Americans (1959).

4. Jamie Allen, Lisa Hostetler and Jessica McDonald, Nathan Lyons: In Pursuit of Magic (Rochester NY: George Eastman Museum, 2019). 304 pages. $\$ 55$.

5. For more context on Nathan Lyons, see: Jessica McDonald, Nathan Lyons: Selected Lectures and Interviews, (Austin TX: The University Press of Texas, 2012).

[UPT is also the printer of the catalog In Pursuit of Magic where the duotone printing adding a yellowish gray to Lyons's otherwise neutral photographs is not totally successful; neither is the choice of a bland photograph for the cover, probably selected by the graphic designers who needed a simple background for their text, not really representing the work shown inside the book. Maybe, just a subjective note form the author of this review!]

\section{ABSTRACTS}

Nathan Lyons (1930 - 2016) lived in Rochester NY from 1957 to his death. He was a curator then an assistant director of the George Eastman Museum (1957 - 1969), working with Beaumont Newhall and Minor White, the co-founder of the Society for Photographic Education (1963) and Oracle (international conference of photo historians and curators since 1983), the founder of Visual Studies Workshop (1969) and its magazine (Afterimage, 1972 - 2018), and a consultant for the National Endowment for the Arts and the New York Foundation for the Arts (president 1976 1991). Before being a curator, an educator, a theorist (among others, the snapshot esthetic, the social landscape, sequences \& series, the photo-book), an advocate for visual literacy, and a keyfigure in post-WWII American photography, he was a photographer-artist who looked at urban America with a sometimes amused, sometimes critical eye. Whereas Lyons photographed in black-and-white for over fifty years, a great space in this exhibition was dedicated to his recent digital color work. His curating, writings and photographs have challenged and expanded the medium in many ways (ICP Infinity Award for Lifetime Achievement in 2000), was he, with his latest work, achieving the same goals?

Nathan Lyons (1930 - 2016) a vécu à Rochester NY de 1957 à 1960 assumant successivement les fonctions de commissaire d'expositions et de directeur adjoint du musée George Eastman (1957 1969), de co-fondateur de la Society for Photographic Education (1963) et d'Oracle (conférence internationale annuelle des historiens et commissaires d'exposition en photographie depuis 1983), de fondateur du Visual Studies Workshop (1969) et de son magazine Afterimage (1972 2018). Il a siégé aux commissions du National Endowment for the Arts et de la New York Foundation for the Arts (président 1976 - 1991). Bien que commissaire d'exposition, enseignant, fondateur d'institutions photographiques, éditeur, théoricien (l'esthétique du snapshot, le paysage social, séquences et séries photographiques, le livre photographique...) et un personnage-clé de la photographie américaine de l'après Deuxième Guerre mondiale, Lyons est avant tout un artiste-photographe qui tourna son objectif sur le paysage urbain colorant son 
approche d'amusement, d'humour, d'ironie critique parfois. Il a photographié en noir-et-blanc jusqu'au début des années 2000, cependant l'exposition consacre une large part à ses photographies numériques récentes en couleur. Son œuvre, tant théorique que photographique, consacrée par le Prix Infinity de l'International Center of Photography en 2000, a sans cesse interrogé la photographie et la culture américaines. Cet essai se propose aussi d'analyser ces travaux en couleur et de voir en quoi ils peuvent ou non prolonger ou simplement compléter l'œuvre?

\section{INDEX}

Subjects: Trans'Arts

Keywords: Black and white photography; color photography; George Eastman Museum; Nathan Lyons; photography; photo-book; photography; American photography; exhibition; retrospective; Rochester; sequence; series; social landscape; Visual Studies Workshop.

Mots-clés: Couleur ; exposition ; livre photographique ; Lyons ; Musée George Eastman ; Nathan Lyons ; noir et blanc ; paysage social ; photographie ; photographie américaine ; photographie couleur ; photographie noir et blanc ; rétrospective ; Rochester ; séquence

\section{AUTHOR}

\section{BRUNO CHALIFOUR}

Université de Lyon 2 - Louis Lumière 